Carolina 29208. Contributions will be used to endow a chair in his name.

Raymond A. Moore

University of South Carolina

\section{Frederick C. Mosher}

Frederick C. (Fritz) Mosher, professor of government and foreign affairs at the White Burkett Miller Center of Public Affairs, University of Virginia, who recently received posthumously the John Gaus Award of the American Political Science Association, died peacefully in his sleep at his home in Charlottesville on May 21, after a long illness brought on by emphysema. During the final weeks of his illness, which he knew to be terminal, he tried repeatedly to dictate parts of a lecture that might be read at the time of the award. This effort proved unsuccessful, although it was another demonstration of his persistence in any scholarly activity once undertaken.

A memorial service was held in the Dome Room of the Rotunda, University of Virginia, on May 27, at which over 20 members of his scattered family gathered, along with over 100 colleagues and friends. Recollections of his life and work in the diverse aspects of his career were offered by colleagues, relatives, and friends.

In opening the service, Kenneth W. Thompson, Director of the Miller Center, made a statement about Fritz Mosher's life and contributions that included the following:

His biography as citizen/scholar is an unfolding pattern of dedication to the city and the common good ... His life's work is a parable of public service, scholarship, and teaching. This afternoon we hope simply to commemorate and celebrate a few brief chapters in an immensely rich and full human story. ... .

So far as I know, he never received 'a best teacher award' but he prepared scores of students for high responsibility. He never claimed to be a political theorist but he had read more American political thought than all the self-appointed theorists. He was an indifferent member of the leading professional societies, with one exception perhaps, yet each selected him for its highest honors. He pleaded ignor- ance in fields such as foreign policy, yet gave leadership to the Herter Commission and wrote the definitive work on foreign policy and transitions ...

He gave himself to the Miller Center beyond anything I can recount and did so in literally every dimension of its work. . . . To our scholarship, he brought immense professional prestige and large scholarly output. In our Forums, he was a faithful and energetic presence. Within our national commissions, he contributed from vast experience and unquestioned knowledge. To the University, he gave proof we were serious. . . . His legacy provides guidelines for all who would serve the Center in the years ahead.

When Fritz Mosher graduated "magna cum laude" from Dartmouth College in 1934, he was recruited almost immediately for a beginning position in the new Tennessee Valley Authority, most of his Dartmouth classmates had great difficulty in that depression year in getting jobs at all, especially jobs that had good career prospects. He was assigned to a research assistant position in the TVA Social and Economic Division, where I was already in place, and started work initially under my supervision. He was obviously bright, energetic, and ambitious. The basis for a life-long friendship was firmly laid during the two years while we were both with TVA, which we both left for different reasons in 1936.

At the time of his graduation from Dartmouth, Fritz had evidently not yet formulated any firm ideas about his long-term career objectives, except that he did not wish at that time to follow in the footsteps of his well-known father into university teaching. But in those early years of TVA, he was fascinated by what he saw going on and by the opportunities for administrative work in government agencies. By 1936 he could also see that he needed a better credential for such work than his Dartmouth B.A. So he went to Syracuse University-one of the few institutions offering graduate programs in public administration in those daysfor an intensive two-year program leading to an M.S. degree in that field.

After that, he spent a year with the Public Administration Clearing House in Chicago and then moved to a supervisory position with the Civil Service Department of the Los Angeles City Government. It was there that he met Edith Kern and they were married.

In 1941, some time before Pearl Harbor, Fritz decided to join the rapidly expanding War Department, and the Moshers moved to Washington. After Pearl Harbor, Fritz soon went into uniform as an officer in the Army Air Force, rising to the rank of major, and eventually receiving the Legion of Merit Award. Even while in uniform, Fritz was concerned mainly with military administrative matters, working out of the Pentagon. After the war, he served for a time as assistant personnel director in the United Nations relief agency (UNNRA) and then moved to the U.S. Department of State, where he was assistant director of Planning for the Foreign Service in the backwash of the Foreign Service Act of 1946.

By 1949, however, Fritz had decided that he did want an academic career, and returned to his roots as a professor of political science at Syracuse University. In 1951-52, he took leave from Syracuse on a Ford Foundation Faculty Fellowship for a year at Harvard, where he completed a doctorate in public administration (DPA). He was back at Syracuse from 1952-1957, during which he served as editor-inchief of Public Administration Review, 1953-56, and published his first book, Program Budgeting: Theory and Practice, in 1954. From

\title{
CORRECTION
}

A correction has been requested for the "In Memoriam" published in September 1990 PS on Marver and Sheva Bernstein. The word "ironical" was incorrectly typed in the following sentence for "irenical." The sentence should read as follows: He sought wisdom; and, being irenical by nature, he also sought consensus. 
1957 to 1959 , he led the University of California's Administrative Science Program at the University of Bologna and co-authored a book on administrative science, published in Italian, and also published two years later in Spanish.

In 1959, Fritz and his family returned from Italy and he took up residence as a member of the faculty of the University of California at Berkeley. Thereafter he continued to be a prolific writer and teacher on government finance, budgeting, and personnel administration. On leave in 1961-62, he returned to Washington as staff director for the privately funded Committee on Foreign Affairs Personnel (the Herter Committee) and wrote for it Personnel for the New Diplomacy. Back at Berkeley, after books on government finance and governmental reorganization, he produced what may have been his most notable book, Democracy and the Public Service, 1968, which brought him the Louis Brownlow Memorial Book Prize in 1969. A 2nd edition was published in 1982.

Also in 1968, Fritz and Edith came to the University of Virginia at Charlottesville. By that time Edith had her Ph.D. from Berkeley, their children were grown, and she joined the faculty of Virginia's Curry School of Education for teaching and research in the fields of educational politics and finance. Fritz held a chair appointment in the Woodrow Wilson Department of Government and Foreign Affairs, with an initial year for research and writing free of classroom duties.

Within two or three years after arrival, Fritz was appointed to head an intra-university task force, which proposed the creation of a Graduate School of Public Affairs. Eventually that proposal was dropped but, in the years that followed, Fritz did much to give character to the teaching of public administration at Virginia. He also continued to author, co-author, or edit one major book after another: Programming Systems and Foreign Affairs Leadership, with John Harr, 1970; Watergate: Implications for Responsible Government, 1974; American Public Administration: Past, Present, Future (Ed.), 1975; Basic Documents of American Public Administration, 1776-1950 (Ed.), 1976; The GAO:
The Quest for Accountability in American Government, 1979; Basic Literature of American Public Administration, 1878-1950 (Ed.), 1981.

In 1980, at the age of 67, Fritz "retired" from his chair appointment in the department, but immediately moved to a professorial research and writing appointment in the University of Virginia's White Burkett Miller Center of Public Affairs. The Center, funded originally by a wealthy Virginia alumnus for the study of the Presidency-with insistence that it not be dominated by what he considered Virginia's excessively liberal faculty - was being led by that time by Kenneth W. Thompson, a former vice-president of the Rockefeller Foundation. Its program had broadened considerably after Miller's death and under

Thompson's leadership.

At the Center, Fritz soon became a major influence and one of its most productive scholars. It undoubtedly fulfilled some of the dreams he had entertained for a graduate school of public affairs at Virginia. Although it offered no courses and recommended no degrees, it had some faculty of varying ages and statuses, often on visiting appointments, and a group of graduate students on fellowships as research assistants.

From time to time, the Center has succeeded in appointing and funding national commissions on major problem areas, commissions usually made up largely of public figures currently or previously involved in the problem areas under study. Fritz provided staff assistance or advice for a number of such commissions, most notably the Center's Commission on Presidential Transitions and Foreign Policy, co-chaired by two former Secretaries of State, William P. Rogers and Cyrus R. Vance. That work led to Fritz's last major book, Presidential Transitions and Foreign Affairs, 1987, co-authored with W.

David Clinton and Daniel G. Lang.

In a Foreword to that book,

Kenneth Thompson wrote:

For more than four decades, Professor Mosher has been among a handful of leading scholars of public administration recognized internationally as well as nationally. At this stage in his career, he is considered to be the doyen of American authorities in the field. In 1981, Mosher was the second recipient of the Dwight Waldo Award, which is one of the highest honors accorded living scholars of public administration.

Also while at the Center, Fritz coauthored and co-edited, with Richard J. Stillman II, Professions in

Government, 1982; produced the 2nd edition of Democracy and the Public Service, 1982; another of his most important books, $A$ Tale of Two Agencies: The General Accounting Office and the Office of Management and Budget, 1984; and edited several other Miller Center publications.

Years ago, the American Society for Public Administration established the annual William E. Mosher Award for "the most outstanding PAR essay by an academician." William Mosher had been famous for decades in his field as the Dean of the Maxwell School at Syracuse University. In 1988, ASPA decided

to redisignate the William E. Mosher Award as the William E. Mosher and Frederick C. Mosher Award to celebrate the contributions of both father and son. By pairing them, APSA honors the uniqueness of their twogeneration achievement.

At the Memorial Service held on May 27, David M. O'Brien spoke for the Department of Government and Foreign Affairs in a statement that included the following:

I remember as a graduate student first reading with admiration Fritz's book Democracy and the Public Service. Later, when I arrived here, I found a kindred spirit. . . .

Invariably, he was helpful in counseling young faculty on departmental matters, whether they appeared big or small. . . . Fritz provided a reassuring perspective. ...

He was excited by the opportunities and the possibilities presented by the University's push toward national recognition. I think he shared as well the ideals of the University's Founder. He certainly shared Thomas Jefferson's devotion to developing practical knowledge and dedication to improving the management of public affairs. ... .

As a teacher, a scholar, and a life-long student, Fritz embodied a healthy and refreshing skepticism. He neither suffered true believers, nor succumbed 
to the enticements of those who would make him a cult-figure in the field of public administration. He was repelled by both, and too busy to bother with either. ...

Fritz Mosher was a truly kind and caring man. ... . He made a difference and a mark on all who knew and worked with him. We are grateful for being so enriched and blessed.

The family suggests that memorial gifts may be made to the MosherAppleby Fund, Maxwell School, Syracuse University, or to the White Burkett Miller Center for Public Affairs, University of Virginia.

Paul T. David

Professor Emeritus

University of Virginia

\section{Donald Winston Smithburg}

Donald Winston Smithburg died May 2, 1990, in Albuquerque, New Mexico. He was Professor Emeritus in the Division of Public Administration at the University of New Mexico. He is survived by his wife, Mary McAnlis Smithburg, a son, Donald R. Smithburg, and a daughter, Laura Smithburg Byrne. Professor Smithburg was born in Seattle, Washington, on May 9 ,
1916. He received a A.B. degree in political science from the University of Washington in 1937. Later he did graduate work at both the University of Washington and the University of Minnesota, and in 1951 he was granted a Ph.D. degree in political science and public administration from Harvard University.

During his career, Smithburg served in a variety of governmental and academic positions. From 1942 to 1945 , he was a Procedures Analyst with the U.S. Government in Washington, D.C. From 1946 to 1967, he was at the Illinois Institute of Technology in Chicago, advancing from instructor to professor in the department of political and social science, and serving as chairman of the department from 1961 to 1964. During these years, he was visiting lecturer at various times at the University of Chicago and Northwestern University, hosted a weekly interview program on NBC-TV Chicago called "The American Scene," and served as consultant to the Chicago Home Rule Commission. With Herbert A. Simon and Victor A. Thompson, he co-authored the classic textbook, Public Administration, published in 1950 and still in print.

From 1967 to 1972 , he was with the department of political science at the University of Alabama in Huntsville, where he served as department chairman, director of the masters program in administrative science, and director of the division of social and behavioral sciences. He was also Consultant on Organization to the Army Missile Command at Redstone Arsenal in Huntsville.

Professor Smithburg was at the University of New Mexico from 1972 until his retirement in 1981, first as visiting professor and then as professor of public administration. As professor emeritus, he continued to teach occasionally until prevented by failing health. He also served a term as president of the New Mexico Chapter of the American Society for Public Administration. He will be remembered by his colleagues as an engaging and faithful friend, by his students as an experienced and knowledgeable teacher, and by the academic community as a well known contributor to his field of study.

Ferrel Heady

Professor Emeritus

University of New Mexico 